\title{
The Role of Professionals in Two Nature-Based Activities in Brazil for Visitors' Connection with nature: Rock Climbing and Birdwatching
}

\section{O papel dos profissionais em duas atividades de lazer na natureza na relação dos visitantes com a natureza: escalada em rocha e observação de aves}

\author{
César Teixeira Castilho, Christianne Luce Gomes
}

\begin{abstract}
This study aims to analyze the role of professionals involved in nature-based activities in the city of Belo Horizonte, Brazil and surrounding regions, namely: rock climbing and birdwatching. The research was based on two key questions: "How does the role of these professionals vary with different kinds of leisure experiences in nature?" and "What are the issues addressed in the discourse and practices of these professionals regarding environmental awareness and environmental degradation aspects?" The methodology applied herein was based on a qualitative approach to data collection. Data was collected through participant observation and semi-structured interviews, which included 15 participants who worked as guides in this region. Participant observation took place during trips organized by such professionals, focused on observing the relationship between guides and participants, their behavior towards nature, and the contact established with the villages in which they developed leisure activities. The results indicated that the professionals who work in nature-based activities first came into contact with these experiences through family influence, during childhood. From such initial contact, they started to seek technical development in undergraduate courses, extension courses, and organizations that aim to further professionalize the field. Issues that involve environmental awareness and environmental degradation seem to have little relevance in the discourses and practices of rock climbing professionals. Otherwise, professionals engaged in wildlife viewing demonstrated greater sensibility to environmental issues. A less dichotomous view, in which barriers between human beings and nature are narrowed, can be achieved through these experiences of nature-based activities and, in this aspect, the professionals involved must be considered as extremely relevant.
\end{abstract}

KEYWORDS: Nature-Based Activity; Professionals; Environmental Issues. 


\section{RESUMO}

O presente estudo possui como objetivo analisar o papel dos profissionais que atuam no campo das atividades de lazer na natureza na cidade de Belo Horizonte (Brasil) e arredores, levando em consideração duas modalidades: a escalada em rocha e a observação de pássaros. A pesquisa em questão baseou-se em duas perguntas iniciais: "como se dá a atuação desse profissional levando em consideração diferentes atividades de lazer na natureza?" e "Quais os aspectos abordados nos discursos e nas práticas desses profissionais quando se pensa na consciência ambiental e degradação do meio ambiente? A metodologia da pesquisa em questão teve um cunho qualitativo e associou a pesquisa bibliográfica à pesquisa de campo, na qual os dados foram coletados por meio da observação participante e entrevistas semiestruturadas com 15 profissionais que atuam no âmbito do lazer na natureza na região privilegiada. A observação participante aconteceu durante as viagens organizadas por esses profissionais e, além da sua atuação, buscou-se observar: a relação com os praticantes das modalidades, 0 comportamento em relação à natureza e o contato estabelecido com os vilarejos nos quais se desenvolviam essas experiências. Os resultados evidenciaram que os profissionais que atuam no lazer na natureza iniciam uma aproximação com essas experiências através da influência familiar, durante a infância. A partir desse primeiro contato, eles buscam um melhor aprimoramento técnico em cursos de graduação, cursos de extensão e em organizações que objetivam tal profissionalização. Questões relativas à consciência ou degradação ambiental parecem ter pouca importância quando analisamos os discursos e as práticas dos profissionais que atuam na modalidade de escalada de rocha. Por outro lado, os profissionais que atuam na atividade de observação de vida selvagem evidenciaram uma maior sensibilidade quanto às questões ambientais e uma maior influência nesse aspecto no contato com os praticantes. Uma visão menos dicotômica, na qual as barreiras entre ser humano e natureza se estreitam, pode ser alcançada através dessas vivências de lazer na natureza e, nesse aspecto, os profissionais que atuam nesse segmento merecem grande destaque e importância.

PALAVRAS-CHAVE: Atividades de Lazer na Natureza; Profissionais; Questões Ambientais.

\section{Introduction and Objectives}

This study aims to analyze the role of the professionals involved in nature-based activities guiding in the city of Belo Horizonte, Brazil, namely: rock climbing and birdwatching. Nature-based activities are viewed as an important tool to raise environmental awareness through the experience lived. In this context, such professionals play an essential role in the relationship with visitors and their connection with nature (WEILER; BLACK, 2014; LIMA, 2016). In this study, these professionals are guides who work in the surrounding regions of the named city.

Ecotourism has been considered the fastest-growing segment in the international market (BUCKLEY; UVINHA, 2011). According to Buckley (2000); Buckley and Uvinha (2007), only in 1998, the nature adventure tourism and ecotourism industry answered for approximately $50 \%$ of all tourism activity in the United States and Australia. Taking only the United States into account, the scale of the outdoor tourism industry was estimated at 730 billion dollars annually. 
In Brazil, one of the countries that make up the so-called BRIC countries $^{1}$, the situation is no different. According to a document from the Brazilian Ministry of Environment, nature-based activities have attracted enormous attention from the industry and have an estimated growth range from $10 \%$ to $30 \%$ per year as of 2000 . Furthermore, this topic has been discussed in various media channels and has gained great prominence in the Brazilian tourism context.

Brazil presents a wide range of natural areas with great potential to strengthen tourism in the country, many of these areas protected as Conservation Units - CU. The rich Brazilian biomes and the country's cultural diversity are unique attractions to offer diversified and quality tourism products. For this same reason, recreational activities in nature must be regulated, in order to mitigate potential environmental degradation and, in a second moment, serve as a tool to raise awareness among practitioners.

The increased number of practitioners and enthusiasts seeking such leisure activities is already a phenomenon according to studies in various academic areas, such as tourism (LIMA, 2015, 2016; PEARCE, 1990; PIZAM, REICHEL; URIELY, 2002), sociology (NORBEK, 1974; OLIVIER, 2006), physical education (CASTILHO, 2013; CARNICELLI, 2013; MARINHO 2004; REIS, 2012) and anthropology (NORBEK, 1974), among others (BRUHNS, 2010; UVINHA 2010). The various reasons that lead individuals to seek such nature-based activities have been debated in some academic works as well. According to Gyimóthy and Mykletun (2004) and Walle (1997), this approach of humans with natural environments as an activity of leisure can be analyzed under two distinct prisms: based on the risk theory and based on the insight theory.

These two lines permeate most studies about the reasons that lead the subjects to pursue such activities. However, there is a preference, mainly in the market, for the so-called "Theory of Risk," which is more simplistic and straightforward. According to the researchers (Gyimóthy \& Mykletun, 2004; Walle, 1997), this view of the risk of activities is more attractive and, obviously, more profitable as a consumer product.

Le Breton (2009, p. 94) analyzes the contemporary preference for risk and correlates such behavior of the subjects with an incessant search for novelty, breaking the monotony and, at the same time, a form of fostering individualism. On this subject, the French author states:

Risk, which our institutions combat in multiple scenarios, provides an opportunity to row against the current, to replenish, to escape boredom, immediately intensifying the relationship thanks to an intoxicating activity. It is a shortcut to regain control of an existence surrendered to doubt, chaos, and monotony. When one chooses risk in a leisure activity or personal challenge, it becomes a kind of reservation from which one extracts meaning, strengthens an impaired sense of living or, sometimes, even finds it again after having lost it. (LE BRETON, 2009, p.94) 
On the other hand, the view based on the insight theory allows a broader analysis regarding leisure activities in nature, an understanding in which it is possible to correlate experience, learning, contemplation, and, why not, some amount of risk. Certainly, some people seek adventure in order to experience and overcome risk. But such narrow and limited paradigms need to be supplemented with more useful, general and inclusive theoretical orientations. By viewing adventure in terms of the quest for personal insight and enlightenment, a broader and more useful orientation becomes available; and by recognizing the alternative motives for adventure, tourism professionals can better expand the tools of marketing and embrace tactics such as packaging and programming which are tailored to diverse market segments.

According to the aforementioned authors, the high demand for naturebased activities slip into these two main reasons in some way. Some activities, such as rock climbing, rafting, bungee jumping, adventure racing, and mountain biking have a direct relationship with the sense of adventure, challenge, competition, and adrenaline. On the other hand, there are others modalities, such as trampling, bird watching, and mountaineering that seem to be more harmonious when considering the environment and the conduct of respective practitioners.

The present research intends to contribute to the field of leisure studies by discussing the theory of risk and the insight theory under the spotlight of nature-based activities promoted in Brazil, specifically in the city of Belo Horizonte and surrounding areas. Although all nature-based activities somehow encompass both approaches (i.e., a component related to risk and another component connected to contemplation), in this study we sought to choose modalities that more or less approach each of these two characteristics. Thus, the rock climbing activity has been associated with the risk theory and the wildlife viewing activity has been associated to the insight theory.

When marketed as a product, all nature-based activities tend to be transformed into commodities, a process commonly known as "commodification" (i.e., the experience becomes merchandise). An interesting well-known case of such commodification within the global tourism segment has been happening in the country New Zealand. According to Perkins and Thorns (2001), the experience of adventure tourism in this country is mainly associated with the challenge of overcoming the boundaries imposed by a fake nature. Thus, the simple quest for a harmonious approach towards nature in this type of tourism becomes inadequate in this context. The performance in and with nature is the product that must be sold by the companies, in addition to being the product to be consumed by practitioners (WHEATON; MANSFIELD, 2010; HEAFAIRWEATHER; SWAFFIELD, 2003).

Consequently, it is possible to raise some debates regarding this relationship between the nature-based activities market in New Zealand and how such activities have been used to attract more enthusiasts. According to Reis (2012, p.307) 


\begin{abstract}
Even though his statements are founded on incontestable 'facts', such as the extensive preserved natural areas and the sublime landscapes suitable for a wide variety of outdoor recreation activities, the natural environment is consumed and sold as a product guided by demand, and not so much engaged in as part of 'ordinary' human-natural environment relationships (REIS, 2012, p. 07)
\end{abstract}

It is important to note that, during the field research, numerous testimonies collected were rendered accordingly, as will be discussed later. Such feature allows us to critically analyse collected data, considering the individuals who participated in the study, as well as the scenarios in which the modalities were developed. Unlike New Zealand, Australia and the United States - admittedly developed countries in the nature-based activity sector Brazil still requires further professionalization and new researches that "open the wound" of this subject. A country that houses the world's largest rainforest must be able to discuss environmental issues effectively and critically.

It is precisely this problem that the present study intends to discuss and which constitutes its central axis: the role of professionals that work with nature-based activities in the city of Belo Horizonte and surrounding areas. The theoretical support for this research attempted to relate the nature-based activity segment, the professionals who work in this segment, and its practitioners. Through the two initial questions of the research, "how is the role of these professionals taking into account different leisure experiences in nature?" and "what are the issues addressed in the discourse and practices of these professionals regarding environmental awareness and environmental degradation aspects?", we seek a cohesive discussion between the area's scientific literature and the specificities of the field study. Then, we will introduce the methods used in field research, as well as the results obtained, and the possible contributions to studies about naturebased activities.

\title{
Study Design and Methods
}

Considering that human action is fundamentally symbolic, this research adopted a qualitative approach design. Therefore, it meets the assumptions described by the authors Bodgan and Biklen (2007, p.27) "qualitative research is characterized by: having a natural setting as the direct source of the data, having the researcher as key instrument, being descriptive, being concerned with the process, and tending to analyze data inductively".

Our study focuses on professionals who work with nature-based activities, especially rock climbing and wildlife viewing. In Brazil, these professionals come from different educational backgrounds and little 
government regulation. The nature-based activities in the country are intimately associated with tourism and lack academic discussions mainly on issues concerning the qualification and performance of professionals involved, as well as environment-related issues.

In this research, the professionals involved in data collection were alerted to the specific purpose of the study and the non-disclosure of any personal information. This study was submitted in August 2013 to the Research Ethics Committee (COEP) of the Minas Gerais Public University (UFMG), duly approved in September 2013 by the Committee. Fieldwork began only after the approval of the research project and lasted approximately six months.

\section{Data Collection Procedures}

Data was collected in the city of Belo Horizonte ${ }^{2}$ and surrounding areas. The headquarters of the analyzed groups are located in the city itself. The companies surveyed in this research offer year-round trips through the state of Minas Gerais, particularly to the Serra do Cipó ${ }^{3}$ Park and Northern state areas. The state of Minas Gerais (Figure 1 ) has many places to practice nature-based activates and its rock formation (known among the natives as 'ocean of mountains') encourages further development of this sector.

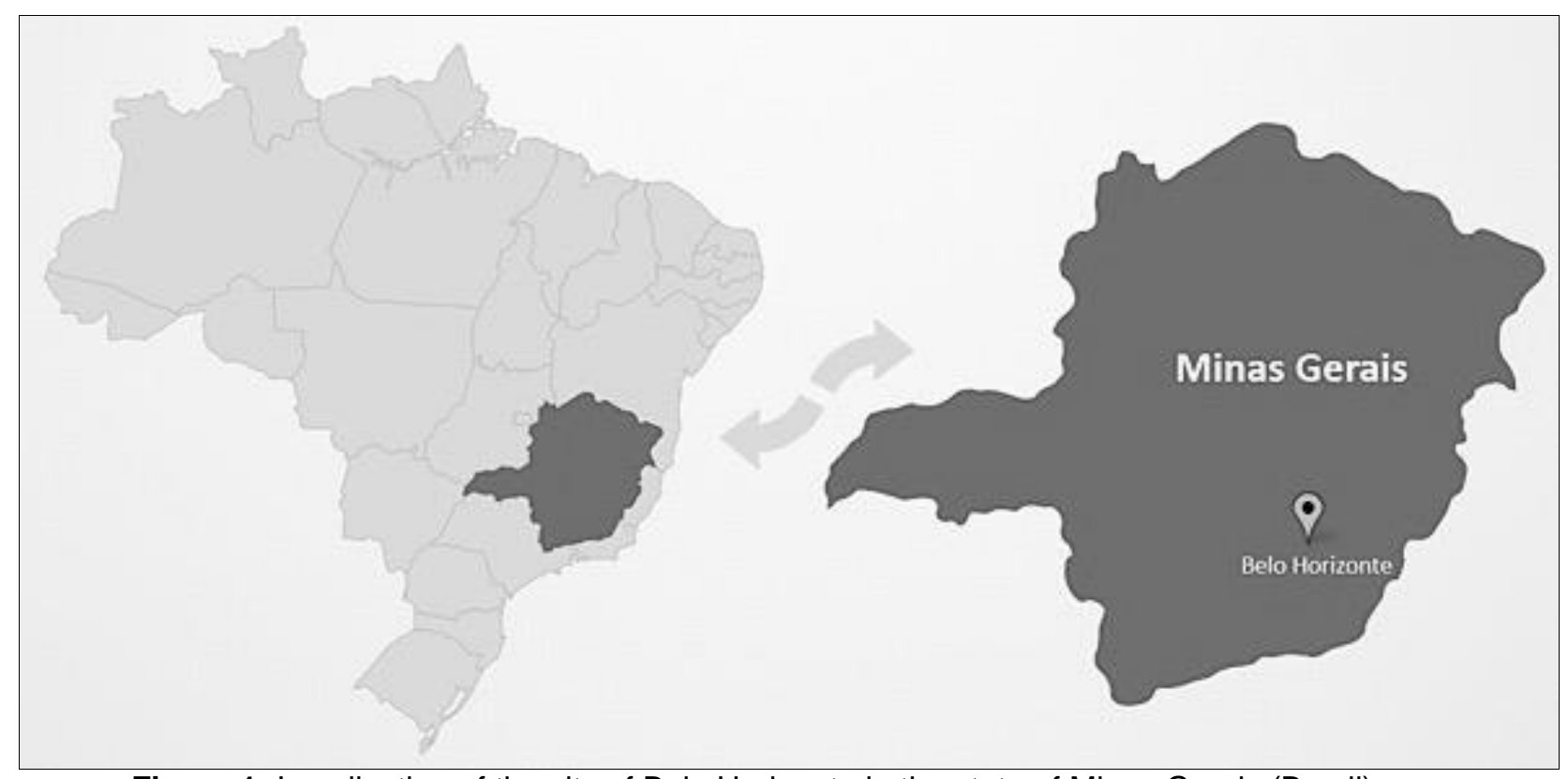

Figure 1: Localization of the city of Belo Horizonte in the state of Minas Gerais (Brazil). Figura 1: Localização da cidade de BeloHorizonte no REstado de Minas Gerais.

In order to collect information concerning human phenomena, the researcher may observe the phenomenon itself or conduct interviews with the key characters directly involved in the research environment (LAVILLE; DIONNE, 1999). The field study adopted two methodological data collection strategies: unstructured observation and semi-structured interviews. 
In this study, field observation was carried out through trips promoted by agencies specialized in nature-based activities and led to a close relationship between the researcher and the object of research. Such method, when applied in a playful, dynamic context, acquires paramount importance because, throughout the time of coexistence, the image of the researcher melts away and the one who was previously regarded as a "stranger" becomes seen as just another person (SEALE, 2012). Thus, the interaction between professionals and practitioners becomes natural and spontaneous in time.

Semi-structured interviews are characterized by greater freedom concerning the order and addition of new questions by the researchers. However, this does not mean that there is no need for prior guidance (LAVILLE; DIONNE, 1999; SEALE, 2012). The interviews were guided by the main objectives of the research (i.e., emphasizing the perception of professionals involved in the two modalities covered by the study and the interaction of such individuals with practitioners). A total of nine interviews were conducted throughout the research.

Initially, screening process was applied for potential enterprises with expertise in the segment of nature-based activities in the city of Belo Horizonte and surrounding areas. After this brief survey, the selection of enterprises to be covered in the study was based on the following criteria: 1) minimum experience of five years; 2) provision of travel or outdoor activities to the public; 3) formal agreement concerning research methods; 4) physical headquarters in Belo Horizonte or surroundings; 5) somehow reflect both theories discussed above, the risk theory and/or the insight theory.

Based on the criteria described above, we finally identified two companies that operate in the areas of rock climbing (CRC) and birdwatching (CBW). CRC is located in Belo Horizonte and has as its main practice the outdoor rock climbing. Although there is also indoor training, during weekends CRC promotes trips to nearby areas of the city in order to provide outdoor training. One of the places most frequently used by CRC is the region called Serra do Cipó.

Five journeys were made to Serra do Cipó, where CRC promoted its practices among practitioners. This detail has brought valuable contributions to understanding the modality, and also generates a close relationship between the volunteers of the research and the researchers themselves. Informal conversations during rock climbing activities were extremely valuable. This enabled assertive questions concerning sensitive topics, such as issues related to the environment.

The other company covered in the study, CBW, is also headquartered in Belo Horizonte and promotes trips all over the South American subcontinent, mainly in Brazil, Bolivia, Venezuela and Colombia. Although birdwatching is not a leisure activity well known by local citizens, the activity is becoming more popular in Brazil, especially due to the biodiversity and the general weather conditions of the country. 
Throughout the fieldwork, four trips were made along with CBW. The practice was held in groups of up to five practitioners, who previously agreed being accompanied by a researcher. Although CBW works with wildlife viewing, in this study all trips were intended exclusively to the practice of bird watching.

Content analysis was the strategy applied for data interpretation of the qualitative research presented in this study, especially the interviews carried out during the fieldwork (BARDIN, 2010). Bardin describes this technique as a group of strategies of communication analysis by means of systematic and objective procedures of message content description from which indicators can be derived to gain knowledge about the conditions of production/reception of these messages.

This information processing methodology can be characterized as a resource to understand the process of formation of perceptions, attitudes and representations within specific groups, with the advantage of systematically comparing data. It is a controlled hermeneutic that allows addressing a wide array of objects of investigation. Its principle is to disassemble the major structure through content elements in order to clarify their different characteristics and, as a result, extract its meaning (LAVILLE; DIONNE, 1999; SEALE, 2012)

This entire process is intended to overcome the level of common sense and subjectivity in interpretation and achieve a critical vigilance towards the analyses of documents, literary texts, biographies, interviews, and observation results (DENZIN; LINCOLN, 2005; MINAYO, 2010). The goal is a serious qualitative approach and a thorough revision of documents acquired during fieldwork activities.

\title{
Results and Discussion
}

\section{Rock Climbing}

\begin{abstract}
"There are moments on high cold mountains, life enhancing moments... they are fragile transient times, when the borders between living and dying seem to overlap, when the past and future cease to exist and you are free" (SIMPSON, 1993, p.227).

"Why climb? For the natural experience; for the danger that draws use ever on; for the feeling of total freedom; for the monstrous drop beneath you. It is like drug" (BUHL, 2000, p.71).
\end{abstract}

The previous reports minimally illustrate the intensity of feelings and emotions surrounding the rock climbing and mountaineering modalities. The people involved in this universe describe their activity with an extreme passion, which often influences the researcher in this field of investigation. A safe distance from such 'contagious adrenaline' is necessary to ensure that analyses are carried out in critical and objective manner. 
The sample comprised 6 male and 2 female professionals aged between 25 and 38. Among them, 5 were graduated in Physical Education and Sports, and 3 were graduated in Biology. A characteristic of the group is their long-term involvement with the modality of rock climbing, averaging over 9 years of recreational or professional practice in the area. This indicates that this group has been working in the field for long enough to understand the modality and identify some performance weaknesses.

Although nature-based activities are somewhat related to their undergraduate courses, all participants reported that during their college years, there was a poor approach regarding the modality itself, which could have been treated more thoroughly. In this sense, the following testimonial is transcribed below:

\footnotetext{
"It was a bit superficial! The course was an elective discipline and appeared at the end of the course, when I was a little more involved with college. The name of the discipline was 'Unusual Sports'. There were several modalities and within those activities, rock climbing was also present. We made some hits on some climbing walls and that was it. The subject was treated in a very superficial way" (Volunteer 3, interview conducted on October 23, 2012).
}

According to the interviewed professionals, practitioners who seek this type of leisure can be characterized into three groups: more experienced practitioners who want to improve their ability in the sport and occasionally participate in competitions; a second group of onlookers who, for some reason, felt attracted to rock climbing; and a third group who practices rock climbing as a regular physical activity in order to enhance quality of life.

The risk and adrenaline elements are very common in the discourse concerning the modality of rock climbing, which is perhaps the reason for such a higher demand for young individuals in this sector. During the fieldwork, this detail became evident and it was also possible to note an element of challenge and dispute among this group.

Unlike other modalities, in rock climbing there is a very peculiar style regarding its practitioners. Usually these are people who emphasize the freedom as a strong expression of the human character. The practitioners appear to have a greater detachment from their own bodies, and this is further evidenced by the clothes they wear, which are most often detached.

In the accounts recorded in the field work, the word "freedom" was, without any doubt, the most used; when we thoroughly analyze this leisure activity in nature, through its restricted, millimetric, controlled movements, we find an interesting contradiction. The "freedom" that is not found in the mathematical method of rock climbing seems to be essential in the practitioner's daily life, whether in their way of relating to the world, or in their way of dressing, often averse to fashion. Rock climber's clothes do not restrict their movements and allow a freedom that is "stolen" from them when 
practicing this activity. In this sense, the words of philosopher and rock climber Krein (2010, p. 14) are enlightening: "climbers experience the freedom they do in part because of the constraints imposed on them and the dangers they face while climbing".

In addition, the importance of nature's role in their lives became quite clear during the fieldwork. Nature, in this process, has an important representativeness, and due to the subject of the research, deserves to be highlighted. The practice of this leisure activity in nature is only possible through this rapprochement between its two main elements: the human being and the rock. However, this proximity observed between individuals and nature is not revealed through heightened environmental awareness. Quite the opposite: the modality seems to end at that point, where nature can be seen as a first-class stage. This observation became evident in the works of the volunteers when they were asked about environmental issues related to rock climbing. The following two quotes highlight this subject:

\begin{abstract}
"Yes, I agree that there is an environmental impact caused by the rock climbing. However, I think that is an extreme discussion. When we stop climbing, the impacts will disappear quickly, maybe in 5 or 10 years. Nevertheless, it is clear that we climbers have difficulty in accepting these rules and, at the same time, we don't really discuss alternatives among us to mitigate such losses" (Volunteer 8, interview conducted on October 29, 2012).

"When trying to create criteria that minimize environmental impacts, we have to deal with our own philosophy of freedom. We like to express ourselves, to move freely, without being restricted by rules or standards. We do not like places like indoor courts, where there are rows and boundaries. It is a paradox that we live and we have to confront it" (Volunteer 4, interview conducted on November 02, 2012).
\end{abstract}

The following quote confirms the words of volunteers 08 and 04 and perhaps leads us to believe that this issue is a worldwide debate. According to Scott (2010, p.133) 'most climbers regard our activity as a freedom sport; in other words', it is free from rules and regulations, we are free to do it where we like, when we like, and with anyone we choose; but this is not entirely true'.

Aspects related to environmental awareness and modalities such as rock climbing and mountaineering have been the topic of extreme debates; a classic case is the climbing of Mount Everest (BEEDIE; HUDSON, 2003), the highest mountain in the world. The current situation in the world's greatest mountains has obscured the practice of mountaineering due to the high risk of accidents created by the 'invasion' of unprepared tourists. According to Beedie and Hudson (2003, p.626), "the distinctiveness of mountaineering is arguably becoming subsumed by the 'mountain adventure tourism' within a more broadly-defined consumer culture". 
The commodification of leisure in nature is understood as a process by which objects and activities are evaluated primarily in terms of Exchange of commercial value (COHEN, 1988) rather than a subjective value and, why not, the education provided by such experiences. The role of tourism is selling a commodity to a group of consumers (FROW, 1997).

The massive intake of the tourism industry into the nature leisure activities, especially rock climbing, aims to plan all the specific characteristics of the modality. Some researchers (MILES; PRIEST, 1999) argue that every outdoor activity that is submitted to intense control or extreme comfort may not be correlated with the element of adventure. In the world of mass tourism, such thorough planning is exactly one of the main features. Thus, the more detailed and planned the travel itinerary, the lower the "peak of experience" (CASTILHO, 2013; CSIKSZENTMIHALYI; SELEGA, 1990; PRIEST, 1990).

In Brazil, due to the increasing number of practitioners and the changes that it brings to the modality, such economic struggle has been discussed in related literature and raises concerns regarding the qualification of professionals who work with nature-based activities. According to Uivinha (2010, p. 163) "the presence of leisure studies in vocational training courses in tourism has been generally tied to a technical design and a reductionist character to the 'commodified' model over which it is based". Volunteers who participated in the study shared the same criticism, moreover, according to themselves; these changes have ultimately been associated with the 'demise' of the true 'spirit of climbing'.

This critical point could be at stake in issues related to rock climbing. This should be discussed among professionals and associations related to the modality in order to prevent such essence from being forever lost. Scientific evidence (BEEDIE; HUDSON, 2003) has suggested a decrease in the 'soul of the climbers'. This result has been related to an overexposure, facilitated by the deployment of strictly urban characteristics in the regions where environmental issues should be paramount.

The region of Serra do Cipó has also staged extensive discussions. Due to the fact that it is a natural park located on the outskirts of Belo Horizonte, the tourism demand in the region has increased substantially without any kind of control or ecological concern. Interviewed professionals indicate an ecological concern in which the clash between environmental awareness and degradation is constant. However, throughout the interviews, it was not possible to identify a coherent dialogue with the practice itself.

In this sense, another important aspect identified among the interviewees was the relationship between economic aspects regarding their performance as professionals and environmental issues. They all know that an excessive number of practitioners in a single pathway can cause irreversible ecological damage. However, they need to somehow juggle this detail with the fact that their profits will also be greater. In this respect, the excerpt from the interview with volunteer 01 is revealing: 
"I believe that the biggest challenge is to balance economic issues and environmental concern. When you take a group of people out to climb, this experience will be registered for a long time. But the paradigm is the following: if I take only five people with me, it will not be as profitable and will not be enough to cover my expenses. So, I have to charge more and I will not be able to do the trip, people will simply not pay. So, it is better to charge less and take more people to the trip. However, when you take fifty people, environmental impacts are much greater. We have no choice" (Volunteer 01, interview conducted on October 23, 2012).

Although the professionals that work with rock climbing are able to critically analyze the phenomena related to degradation and behavior of practitioners, during the participant observation process, it became evident that it is never discussed during the outdoors practice. The technical aspects seem to become increasingly important. The professionals themselves encourage and corroborate accordingly. Aspects concerning environmental issues are rarely prioritized, whether indoors or outdoors.

\section{Birdwatching}

According to Figueiredo (2003), among the sectors of ecotourism, which have been developing nowadays, bird watching is the fastest-growing segment in Brazil. Considered as a leisure activity by nature, birdwatching depends on the existence of a favorable environments and an abundant fauna.

This type of leisure activity involves millions of people worldwide, especially in the northern hemisphere (FIGUEIREDO, 2003), having originated in the mid nineteenth century (MOURÃO, 1999). The sector has a great economic movement in Europe and North America through the sale of books, special clothing, binoculars and other related products and services, such as travel arrangements and expert guides, among other items. According to Yourth (2001), approximately one million British citizens practice this activity and, among them, bird watching is considered the third largest form of leisure.

In Brazil, birdwatching is still taking its first steps when compared to some countries in North America and Europe, especially the U.S., England and Germany. Although Brazil presents features conductive to the development and practice of this embodiment, the number of Brazilians involved in this leisure activity is still small. After hosting the World Conference on Environment and Development (ECO 92) ${ }^{4}$, there was an increase in the dissemination of Brazilian natural resources by the media, and bird watching was gradually disseminated among the general public (PIVATTO; SABINO, 2005).

Birdwatching in North America and Europe is such a strong and developed leisure activity that specialized agencies operating in Brazil focus mainly on foreign audiences. The agency analyzed during the field research has an experience of over ten years in bird watching and focuses on 
Americans and Europeans as their main customers. According to volunteer 02 , the company is strictly focused on foreign audiences and rarely on Brazilians:

\begin{abstract}
"Our public is $100 \%$ foreign, mainly British and Americans. I would say we had more British customers last year. In 2011, we had $60 \%$ of British and $40 \%$ American; eventually, Belgian, French and German customers as well" (Volunteer 02, interview conducted on January 31, 2013).
\end{abstract}

According to the fieldwork, it became clear that the majority of the public interested in this leisure activity has a high purchasing power, high level of education, and a long-term bird watching practice. In agreement with this idea, volunteer 01 reported:

\begin{abstract}
"Clients who seek our service already have some previous experience with bird watching (i.e., they already have certain concepts formed in their minds, which facilitates our work. [...]). So, wildlife viewing is an amazing instrument, first because they are people with good purchasing power and, in most cases, willing to help. It's a super, hyper instrument. I have seen fantastic donations made by some clients! I've seen jeeps being donated, and that's a cool thing to see" (Interview conducted on January 31, 2013).
\end{abstract}

Such donations are made when practitioners find out any connections between the projects and the commitment to environment issues. Through the field observations, it was evident that the participants desire to learn more about visited projects, inquiring the trip guide and locals within these regions. When it comes to the point of concluding a transfer of funds to the project, the people involved are already aware of all the work that is being developed at that location.

The enterprise analyzed in this research holds such approach with environmental projects as one of its top priorities. As mentioned earlier, this contact can provide a donation and thus add value to the activity itself. Although sometimes the relationship between tourism and environmental projects is not very friendly, according to volunteer 02 , this proximity, when performed harmoniously, can generate benefits for both segments.

"I always try to reach out to environmental projects. This enriches my work and certainly the product sold by my company. Furthermore, it can bring economic benefits to the project itself, which is very pleasing. There is a certain rivalry between tourism and biology researchers. Sometimes, researchers have access to some animals and do not want to share it with the tourism area. I agree that tourism can be predatory, but not always; there are several ways to work and deal with tourism" (Interview conducted on January 31, 2013). 
This direct contact between the professionals and their clients is an important tool within nature-based activities. In bird watching, specialized professional qualification and fluency in English are essential. The professionals involved in the field research graduated in biology, tourism and journalism. They constantly take improvement courses in the area and participate in exhibitions around the world, especially in North America and Europe. Such characteristics are in line with the theory developed by Lima (2016) whereby "tour guiding commonly demands eclectically skill, abilities and training in introducing and mediating culture, places, ecosystems, landscapes, and local people attributes".

Although bird watching may seem less predatory than other modalities of leisure in nature, there still are environmental impacts. According to the professionals, the impact is real and apparently seems to be minor, but also raises concerns and an imminent need for discussion between all stakeholders involved. According to the study of Sekerciouglu (2002, p. 284), it is possible to list some negative points that raise concern among the professionals involved in this activity, namely: disturbing birds with birdsong playback and by approaching; increased nest predation and nest abandonment; increased disturbance of rare and/or endangered bird species; visitor-related pollution and habitat destruction, cash from local communities; resentment by excluded locals; and cultural degradation associated with tourism.

The aforementioned aspects indicate that several elements must be questioned, requiring greater organization by the agencies involved in this area. The professionals' engagement plays a major role in this aspect, since it is precisely through their actions that these clashes can be reconsidered, discussed and, therefore, mitigated. Exemplifying these negative aspect caused by the excessive number of tourists, volunteer 09 reports a situation that took place in Venezuela:

"I've been in a region called Gran Savana, where there are some Harpia nests (Brazilian Eagle). I was under a tree, working, and then, suddenly, a Toyota arrived with several tourists. They were all equipped and noisy, driving through an off-road path. These guys arrived, got off with plenty of equipment and watched the nest for no more than 5 minutes. After that, they left. This is a clear example of how you should not approach such a special place. They should have parked their car further back and approached slowly" (Interview conducted on February 01, 2013).

The tolerance of birds is higher for approaching vehicles than for approaching people (KNIGHT; COLE, 1995). Therefore, in activities using motor vehicles, it is recommended that tourists remain inside the vehicle. In addition, it is also advised that the number of persons is reduced to a maximum of 10 people per visit. Knight and Cole (1995) also observed that birds with frequent contact with people are more accustomed and tolerant. Therefore, they suggest the use of areas where there is already previous human exposure. 
Another facet that has been under discussion is the excessive use of playback (i.e. reproduction of birdsong in order to encourage certain bird species from approaching the group). Various dimensions should be analyzed, including the volume used, proximity, and the amount of times that the tool is used to ensure the bird appears to the group. Although professionals seem to be aware of this issue, overuse is still very common. Several times, professionals feel "forced" to use such means in order to satisfy the desire of clients and ensure they do not miss out on the main purpose of the trip.

Professionals who participated in the field study demonstrated a keen understanding of the real possibilities of bird watching in order to promote environmental awareness (i.e. as a resistance tool). This translates into considering actions that counteract exclusionary values of society. When we think about the environmental aspect, we think of education as a synonym for resistance.

Environmental education as political education is committed to the expansion of citizenship, freedom, autonomy, and direct intervention of citizens in the search for solutions and alternatives that ensure a dignified coexistence towards the common good of all (REIGOTA, 2009). During the participation observation process, it was possible to identify a strong relationship between the agency and the villages where the practices occur leading "to protected/improved quality of environmental conditions" (LIMA 2016, p. 20). There is an interesting trade-off between both sides. On one hand, the agency needs the help of the locals, while local populations can raise funds through this work. In Brazil, this interaction is very interesting and should be analyzed in greater depth. On this subject, the words of Volunteer 08 are worth highlighting:

\footnotetext{
"It is interesting to observe how nature-based activities involve many people from the agency and also residents of remote villages. This generates a great responsibility for the professional that works in this area. We must respect each village that welcomed us, and particularly value the work of each person in this network. Unfortunately, the truth is that local guides in the base of the pyramid are often exploited. As an agency owner, I must worry about local guides and especially about their education. One way or another, this will bring benefits to me" (Interview conducted on February 01, 2013).
}

Considering the previous paragraph, it is clear that nature-based activities can reach unimaginable niches. The ultimate purpose of bird watching should not be restricted to the scope of the neat look; on the contrary: the entire process to reach any particular village should be taken into account. A broader view, through the perception of all stakeholders involved, should be prioritized and taken seriously by engaged professionals. 


\section{Discussion}

This final part of the study takes up the two key questions that guided this research in order to identify correlations with the aforementioned results. Considering the two major aspects that promoted dialogues between literature and fieldwork results - peculiarities of professional performance in nature-based activities in Belo Horizonte and surroundings, and issues related to environmental awareness and degradation - it is intended to highlight the most relevant aspects within such context. The goal is to identify common and diverging characteristics perceived in practices and discourses from the professionals that work with rock climbing and wildlife viewing activities.

Professionals interviewed have some common characteristics. In different ways, they all established a 'passion' for nature and proximity to natural environments at an early age. In this aspect, the professionals' parents play an important role based on leisure activities they propose to their children. After being developed, this sensibility seems to have a term for the rest of their lives. Thus, it is pertinent to state that interviewed volunteers foster a close relationship with nature, through a peculiar symbiosis in which the dichotomy between humans and the environment is reduced.

The risk theory and the insight theory are related in some way with this approach, as previously explained. Although the professionals involved in this work are connected with natural environment contemplatively and, accordingly, are closer to the latter theory. On the other hand, when these professionals work with their clients, the risk theory plays an interesting role. In the case of rock climbing, it seems to have an important component in the dispute between the practitioners and the sport's marketing activities. Despite being considered as an individual modality, rock climbing has a strong component related to its element of physical performance.

Considering the professional activities and issues related to the environment, professionals that work in the field of rock climbing have a greater concern focused on technical skills compared to environmental issues. Although a natural environment is paramount for this modality, matters related to environment preservation only gain momentum when there is a political confrontation with any institution dedicated to environmental preservation (i.e., when the freedom emphasized by the interviewed volunteers is somehow threatened).

On the other hand, when analyzing the discourse of professionals who work with wildlife viewing, a deeper discussion beyond technical aspects is more evident. During the interviews with these professionals and informal conversations with practitioners, the interaction between the leisure activity itself and environmental concerns seem to be aligned. In this sense, it is important to note that when the leisure activity enhances other dialogues beyond the practice itself, it becomes an important tool for the critical issues surrounding modern environmental issues.

In some way, nature-based activities that require higher contemplation are developed at a slower pace, and it seems to be against the performance logic in which the time must be optimized all the time. Nowadays, the 
industry's culture tends to privilege the non-reflective 'leisure'. In fact, the market demand involves the physical feeling above all else. Modalities such as bungee jumping, skydiving, and base jumping, among others, provide a 'supersonic' emotional discharge in a relatively low amount of time and simultaneously require a high budget to be performed. Such experiences often take place under a gorgeous natural backdrop, where nature is once again a luxurious 'stage'. In this aspect, Park (2006) makes a 'sharp' criticism by appointing New Zealand as the current Disneyland of extreme sports (i.e., the country's theatre).

Finally, the professionals who work with nature-based activities play a central role when considering a more acute discussion on issues related to the environment. While there are many difficulties in this sector, professionals remain active in this field - whether as work or during their spare time - and all of this involvement has only one explanation: they love their profession and the approach to nature that it provides. In Brazil, nature-based activities require greater attention from the government and also better organization within each modality. In this sense, once again, the professionals are the basis for any discussion.

\section{References}

BARDIN, L. Análise de conteúdo [Content Analysis] (Ed. Revisada). Lisboa: Edições70, 2010.

BEEDIE, P.; HUDSON, S. Emergence of mountain-based adventure tourism. Annals of Tourism Research, v.30, n.3, p.625-643, 2003.

BOGDAN, R.C.; BIKLEN, S.K. Qualitative research for education: an introduction for the theory and methods. Boston: Allyn and Bacon, 2007.

BUHL, H. Climbing without compromise. Seattle: Mountaineers Books; 2000.

BUCKLEY, R.; UVINHA, R.R. Adventure Tourism Management. Butterworth Heinemann, Elsevier; 2011.

BUCKLEY R. Neat trends: Current issues in nature, eco-and adventure tourism. The International Journal of Tourism Research, p.437-44, 2000.

CASTILHO, C.T. Mount Roraima; the contemporary leisure experience. In: AITCHISON, I.C. (org) Education and Outdoor learning: adventure, tourism and sustainable development. London: LSA Publications, p.66-72, 2013.

CARNICELLI-FILHO, S. The emotional life of adventure guides. Annals of Tourism Research, Vol. 43, p. 192-209, 2013.

COHEN, E. The tourist guide: the origins, structure and dynamics of a role. Annals of Tourism Research, p. 5-29, 1985.

CSIKSZENTMIHALYIM; SELEGA, I. Adventure and the flow experience. In: MILES, J.; PRIEST, S. (org) Adventure Education, State College PA: Venture Publishing, p.149-55, 1990. 
DENZIN, N.K.; LINCOLN, Y.S. The Sage Handbook of Qualitative Research (3ํㅡ. Ed.). London: Sage Publications, 2005.

FIGUEIREDO, L.F. A observação de aves. Centro de Estudos Ornitológicos, 2003. Retrieved 10 January 2014 from $<$ http://www.ib.usp.br/ceo>

FROMM, E. On disobedience and other essays. Seabury Press, 1981.

FROW, J. Time and commodity culture: essays in cultural theory and postmodernity. Oxford: Clarendon Press, 1997.

GYIMÓTHY, S.; MYKLETUN, R.J. Play in adventure tourism: the case of arctic trekking. Annals of Tourism Research, v. 31, n. 4, p.855-78, 2004.

KNIGHT, R.L.; COLE D.N. Factors that influence wildlife responses to recreationists. In: SELERCIOUGLU, C.H. (org) Impacts of bird watching on human and avian communities. Environmental Conservations, v.29, n.3, p.282-89, 2002.

LAVILLE, C.; DIONNE J. A construção do saber: manual de metodologia da pesquisa em ciências humanas. Belo Horizonte: Artmed, 1999.

LE BRETON, D. Playing symbolically with death in extreme sports. Body and Society, v.6, n.1, p.1-11, 2000.

LE BRETON, D. Condutas de risco: dos jogos de morte ao jogo de viver. Autores Associados: Campinas, SP, 2009.

LIMA, I.B. Pivotal Role of Tour Guides for Visitors' Connection with Nature: Conceptual and Practical Issues, International Journal of Humanities and Applied Sciences (IJHAS), v.5 n., p.18-22, 2016.

LIMA, I.B.; WEILER, B. Indigenous Protagonism in Tourism Operations and Management in Australia, Brazil, and New Zealand. ASR: CMUJ of Social Sciences and Humanities, v.2, n.1, 2015.

MARINHO, A. Atividades na natureza, lazer e educação ambiental: refletindo sobre algumas possibilidades. Motrivivência, 2004.

MILES, J.; PRIEST, S. Adventuring programming. State College PA: Venture Publishing. Nepal Tourism Board, 1990.

MINAYO, M.C.S. $O$ desafio do conhecimento: pesquisa qualitativa em saúde. Hucitec: São Paulo, 2010.

MONASTERIO, E. The risks of adventure sports/people. The Alpinists, 2007. Retrieved 14 June 2014 from http://www.alpinist.com/doc/web07f/rberik-monasterio

MOURÃO, R.M.F. Observação de Aves. Caderno de Subsídios Observação de Aves. In: MOURÃO, R.M.F.; BARROS C.B. (org). Manual Melhores Práticas para o ecoturismo. Rio de Janeiro, Programa MPE Funbio, 1999.

NORBEK, E. The anthropological study of human play. Rice University Studies; p.1-8, 1974.

OLIVIER S. Moral dilemmas of participation in dangerous leisure activities. Leisure Studies, v.25, n.1, p.95-109, 2006. 
OUTDOOR INDUSTRY ASSOCIATION (2007). Retrieved 10 June 2014, from:<http://www.outdoorindustry.org/gov.communications.php?-

sortyear1/42007>

PARK, G. Theatre country: essays on landscape and Whenua. Wellington: Victoria University Press, 2006.

PIVATTO MA, Sabino J. Recomendações para minimizar impactos à avifauna em atividades de turismo de observação de aves. Atualidades Ornitológicas, 2005.

PIZAN A, REICHEL A, URIELY N. Sensation seeking and tourism behaviour. Journal of Hospitality \& Leisure Marketing, v.9, n.3, p.17-33, 2002.

REIGOTA, M. Meio ambiente e representação social. São Paulo: Cortez, 1995.

REIGOTA, M. O que é educação ambiental. São Paulo: Brasiliense, 2009.

REIS, A.C. Home and Way: Constructions of place on Stewart Island. The International Journal of Research into Island Cultures, v. 6, n.1, 2012.

REIS, A.C.; SHELTON, E. The nature of tourism studies. Tourism Analysis, p.375-84, 2012.

ROSSI, B.; CEREATTI, L. The sensation seeking in mountain athletes as assessed by Zuckerman's sensation seeking scale. International Journal of Sport Psychology, p.417-431, 1993.

SEALE, C. Researching Society and Culture. $3^{\text {rd }}$ Edition. SAGE, Publication, 2012.

SEKERCIOUGLU, C.H. Impacts of bird watching on human and avian communities. Environmental Conservation, p.282-89, 2002.

SIMPSON, J. This game of ghosts. Seattle: Mountaineers Books, 1993.

UVINHA, R.R. Formação profissional em turismo e suas interfaces com o lazer. In: ISAYAMA, H.F., (org) Lazer em Estudo: Currículo e Formação Profissional. Papirus: São Paulo, 2010.

WEILER, B.; BLACK, S. Tour Guiding Research: Insights, Issues and Implications. Channel Viwe Publications, 2014.

WALLE, A.H. Pursuing risk or insight: marketing adventures. Annals of Tourism Research, v.24, n.2, p.265-89, 1997.

WHEATON, B. Mansfield L. Leisure and the politics of the environment, Leisure Studies, v.29, n.3, p.349-51, 2010.

YOURTH, H. Observando e caçando [Watching and hunting]. World Watch, WWI Worldwatch Institute/UMA-Universidade Livre da Mata Atlântica, 2001. 


\section{Notas:}

1 BRICS: is the acronym for an association of five major emerging national economies: Brazil, Russia, India, China, and South Africa.

2 Belo Horizonte is the capital of the Brazilian state of Minas Gerais, located in the Southeast region of the country. As of 2013, the municipality's population is $2,497,175$, consolidating it as the most populous city in Minas Gerais state and the sixth most populous city in the country.

3 The region is located less than a hundred kilometres from de capital, Belo Horizonte, between the rivers São Francisco and Rio Doce. It is a touristic region with various attractions regarding nature-based activities, such as: landscapes of a multitude of waterfalls, caves and trails, which is a veritable playground of practicing rappelling, biking, climbing, rafting and trekking. The fauna and flora are also exuberating. With an extremely high biodiversity, one of the richest in the country, home to endangered species like the maned wolf, the jaguar, and the giant anteater. ${ }^{4}$ Conference held between June 3 and 14, 1992 in Rio de Janeiro, by the United Nations. The purpose of such meeting was to reconcile economic development and environmental preservation, which later became known as sustainable development. $<$ http://www1.folha.uol.com.br/folha/especial/2002/riomais10/o que e-2.shtml>.

César Teixeira Castilho: Université de Paris XI - Paris Sud, France.

E-mail: castcesarster@gmail.com

Link para o currículo Lattes: http://lattes.cnpq.br/5940278177704234

Christianne Luce Gomes: Universidade Federal de Minas Gerais, Belo Horizonte, MG, Brasil.

E-mail: chris@ufmg.br

Link para o currículo Lattes: http://lattes.cnpq.br/3397229266029271

Data de submissão: 5 de maio de 2016

Data de recebimento de correções: 15 de fevereiro de 2017

Data do aceite: 15 de fevereiro de 2017

Avaliado anonimamente 